\title{
MIR518E Gene
}

National Cancer Institute

\section{Source}

National Cancer Institute. MIR518E Gene. NCI Thesaurus. Code C105371.

This gene may be involved in the repression of gene expression. 